\title{
Value Orientations and Fertility Intentions of Finnish Men and Women
}

\author{
ANNELI MIETTINEN, M.Soc.Sc., Researcher \\ PIRJO PAAJANEN, M.Sc. (Health care), Researcher \\ The Population Research Institute, The Family Federation of Finland
}

\begin{abstract}
In this paper we examine how personal values and attitudes are related to childbearing intentions among 18-40-year-old Finnish men and women. We focus on religious and individualistic values and on attitudes towards children and the family, as well as attitudes towards work and gender roles. The impact of value and attitude orientations and situational factors on fertility decision-making are investigated separately at parities 0,1 and 2 using logistic regression. Our study uses a subsample of 1,237 men and women drawn from the PPA2 survey of the attitudes of Finns towards family and children, family policy measures, values in life as well as their fertility intentions. We find that information on personal values and attitudes does increase our knowledge on determinants of childbearing intentions and decision-making, although not all our initial hypotheses concerning the association, or direction of the association, between certain attitudes and fertility intentions were confirmed in the data. Religious values, as well as work-related attitudes and individualistic values appeared to have little bearing on childbearing intentions, while various attitudes towards children were related to intentions to have (more) children. In addition, a conservative familistic attitude was related to intentions as well as gender role attitudes. The impact of values and attitudes varied by parity, providing support to the notion that childbearing decisions are made sequentially ${ }^{a}$.
\end{abstract}

Keywords: Fertility intentions, parity, values, attitudes

\section{Introduction}

All over Europe after the Second World War, though at a varied pace, fertility has continued to decline and in many countries has reached a level clearly below replacement (2.1). Most European countries are currently also experiencing similar changes

\footnotetext{
${ }^{\mathrm{a}}$ We have not included all the tables from the logistic regression analyses performed for this study in this article. Additional tables can be obtained from the authors.
} 
in the family and household structure, in childbearing and in the age structure of the population. These trends include increasing age at first birth and a decreasing number of children being born, an increasing proportion of children being born outside marriage, a rise in different forms of cohabitation, an increasing number of single-person households among young adults and an increasing number of one-parent families and reconstituted families.

In Finland today, childbearing decisions are made in a context where the majority of women, and especially mothers, are employed, and the younger generations and particularly young women spend a long time in education and end up with a relatively high educational degree. The labor force participation rate of women aged 20-40 is over 77 percent, and the proportion of women among persons completing a university degree has risen to 60 percent during the $1990 \mathrm{~s}$. The state has also substantially reduced the costs related to children and childbearing as well as supported reconciliation of parenthood and employment with various family policy measures. Compared to many European countries, fertility in Finland has remained rather stable and on a relatively high level since the mid-1970s (1.6-1.8). Despite this, fertility has continued to be under replacement level, leading to a diminishing number of children being born.

A large part of the fertility decrease during the last decades can be explained by the postponement of the first birth to a later age, and a decrease in third or higher order births. The median age of women at first birth has risen from about 23 in the late 1960 s to well over 27 in 2001 . The proportion of women still childless at age 35 was about 25 percent in 2001, seven percentage points higher than in the mid-1980s (Statistics Finland 2002 and 2001).

Although fertility levels have fallen below replacement, they are not close to zero and, in fact, in many countries the decrease has been leveling off and period fertility rates have stabilized around 1.5-1.9. Among those who become parents, a family with two children seems to have become the norm. In fertility surveys the ideal family size has settled at a little over two children, and the proportion of those who wish to have no children at all or only one child has remained on a low level (Coleman 1996). Also in Finland, the proportion of women progressing towards higher parities, three or four children or more, has decreased continuously, although in the 1990s a slight increase in third- and fourth-birth intensities could be noticed (Vikat 2002).

Women's labor force participation and increasing educational participation have received some attention in research on fertility trends and behavior in Finland. So far, relatively little research has been focused on the impact of values and attitudes on fertility decision-making in Finland (except, for example, Ruokolainen \& Notkola 2002). With the exception of FFS studies from the 1970s and 1980s, we have little knowledge of values related to childbearing or of family size ideals among Finns. 
In this paper we examine the association of personal value orientations and attitudes with childbearing intentions among 18 - 40-year-old men and women using data from the PPA2 survey conducted in Finland in spring 2002. This study is motivated by the idea that if we want to understand why men and women decide to have or not to have a child, it is important to also incorporate value and attitude orientations in the study of fertility decision-making. Information on personal aspirations and attitudes can provide additional information above the other fertility determinants, especially in the case when individuals and couples are behaving 'against the norm', i.e. when they decide not to have children at all or stop at parity 1 , or, respectively, when they want to continue towards third or higher order parities.

\section{Rational choice and ideational theories on fertility}

According to rational choice or economic theories on fertility, reproductive decisions are based on rational thinking and calculation in which children are regarded as only one of the many possible ways of self-fulfilment in life (Easterlin 1966; Becker 1993). When deciding upon whether to have a child, individuals and couples consider pros and cons related to childbearing in comparison to available alternative activities. Having children may involve considerable costs in the form of employment opportunities, income spending, partnership behavior, etc. Children involve not only opportunity costs and direct expenditures, but their utility has also declined even further as children are no longer required to support their parents. The emotional satisfaction from children can be achieved most economically by having one or two children.

On the other hand, ideational or normative theories argue that norms and values play a central role in fertility behavior. Sociological studies have suggested that cultural or ideological climates can, in the absence of sanctions, have a similar impact on fertility as norms and values (Lesthaege 1983, Preston 1986). Value of children -studies have stressed the role of non-instrumental motives and the immanent values which children satisfy that are behind the parents' desire for children. Children are valued as sources for feelings of accomplishment, creativity and stimulation (Palomba \& Moors 1995; Hoffman \& Manis 1979), sources of social capital (Schoen et al. 1997), or sources to reduce uncertainty and increase marital solidarity (Friedman et al. 1994; Myers 1997).

On the macro level, secularization, the ideology of responsible parenthood, growing individualism or post-materialism, the empowerment of women and changing expectations towards motherhood and parenthood are believed to be the underlying causes of low fertility in the Western world. Having children may still well form part of a postmodern idea of self-fulfilment. But at very low fertility levels, the timing of births clearly becomes exceedingly important. The crucial factor that appears to determine completed family size of modernists and postmodernists is not that they 
differ substantially in stated ideas, wishes, expectations or preferences. Most likely postmodernists just have important competing preferences and priorities. They began childbearing late: at every age they have below-average numbers of children born. (van de Kaa 2001.)

It can be assumed that both sets of elements, the ideational elements and the economic constraints, contribute to family formation and fertility behavior. The recent evolution of society has brought about a great variety of opportunities in education, work and leisure time. People's standard of living is largely determined by the level and quality of education, by the degree of commitment to societal goals and motivation for self-realization. In addition to economic costs, social and cultural changes play a very meaningful role in encouraging people to react in an individualistic manner and to break with longstanding behavioral patterns. Effective contraception has made it possible to plan if and when to become a parent. It may be expected that motivational factors, personal values and considerations have more importance in determining fertility behavior when social norms are losing their predictability in describing the family formation process.

Much research has focused on 'hard facts' behind fertility behavior. This can be partly explained by the difficulty in establishing a causal link between values and fertility in cross-sectional or retrospective studies. Studies on values and fertility have demonstrated that ideas about appropriate ways of living are linked to life course decisions, but values may also adapt to changes in family life (Thomson 2002; Moors 2002). It can be expected that personal values and attitudes affect how economic and situational constraints to childbearing are perceived and the assessment of rewards and costs related to alternative activities. In this respect, studies on childbearing decisionmaking and fertility intentions provide one possible way to include values and attitudes in the study of fertility behavior.

\section{Fertility intentions and realized fertility}

Research on fertility behavior and fertility intentions has shown that the link between expressed fertility intentions and subsequent fertility is often very loose. Often, the number of children intended or desired by the respondents is used to measure fertility intentions. Preferences and intentions concerning childbirth and number of children may well reflect the person's general ideas about children and childbearing, but their validity in predicting actual fertility behavior is often questioned. With the increasing awareness of and access to reliable contraceptive methods, actual fertility has approached the ideal, and gradually the ideal family size has exceeded the actual number of children in families. In Finland, it was found that the actual number of children women had was smaller than their ideals already in the early 1970s. The ideal number of children has been found to depend on the phase of life, and the ideals of the young are often unrealistic and may change later along with experience (Ritamies et al. 1984). 
Although it is agreed that individuals are poor predictors of whether they would initiate childbearing, the same factors that predict fertility behavior are found to predict fertility intentions (Rindfuss et al. 1988). In this line of thinking, intentions are important because they synthesize the influences of an individual's background and attitudes and mediate between those characteristics and behavior, the transition to parenthood.

According to Miller and Pasta (1995), fertility behavior can be conceptualized as a general psychological sequence leading from latent motivational traits to realized fertility behavior. In the first phase, latent fertility-related traits and motivations are activated into conscious desires, which, in turn, are translated into intentions. Desires express personal wishes and as such do not lead to realized behavior. Intentions are different from desires in that they take into account the behavioral control or context relevant to childbearing behavior. This means that childbearing intentions are formulated in relation to perceived constraints that prevent a person from doing what he or she desires. When desires represent the integration of antecedent motivations and attitudes, intentions represent the integration of antecedent personal desires, and perceived situational, interpersonal, social and other constraints to behavior. In the next phase, intentions generate instrumental behavior for the achievement of the intended goal. Miller and Pasta have identified three types of desire and corresponding intention which are relevant to fertility: the desire/intention for a certain number of children, the desire/intention for timing the birth, and the desire/intention for a child or for another child if there are already children present.

A number of longitudinal studies have provided evidence that fertility intentions can, indeed, have predictive value concerning future behavior (Schoen et al. 1999; Monnier 1989; Miller \& Pasta 1995). Contrary to the mediation hypothesis, Schoen et al. (1999) argue that intentions have independent value in explaining subsequent fertility. Timing expectations and especially the certainty of intentions were found to be strongly related to future fertility behavior, especially among married persons. Research has also pointed to the importance of time as an intervening variable: the more time has elapsed between the measurement of intentions and the behavior, the less predictive intentions are (Miller \& Pasta 1995; Thomson 1997).

We assume, in accordance with White \& Kim (1987), that childbearing decisionmaking is sequential and that individuals and couples proceed towards their final family size via consecutive choices, in which they consider the alternatives in respect to their experiences and situational factors. Family formation intentions reflect these considerations. While the decision to have a first child is a choice of parenthood over non-parenthood, decisions to have subsequent children are essentially different, in that parents already have the experiences gained from the previous children. As circumstances and alternatives are expected to vary by parity, so too are factors related to childbearing decisions. Accordingly, personal values and attitudes enter at every stage of family formation, but relevant values may change during the family forma- 
tion process, as well as the relative importance of values/attitudes and other factors. In his study, Bulatao (1981) found that values and disvalues related to having a(nother) child in the family varied according to the prospective birth order. Personal affection and closeness to one's spouse were related to lower birth orders, while gender preferences and financial concerns were expressed more often in relation to higher parity births.

\section{Values, attitudes and fertility behavior}

The general attitudes of the population towards the family and children form the context in which subjective preferences and assessments regarding family formation are made. There has been a dramatic and pervasive weakening of the normative imperative to marry, to have children and to maintain separate roles for males and females. The power of socially shared beliefs that individuals should follow these particular family patterns is diminishing. However, while more people are now accepting the diversity of behavior, they still value and desire marriage, parenthood and family life for themselves (Thornton 1989; Palomba 1998; Palomba \& Moors 1998).

A decision to become a parent is one of the most complex lifetime judgements that individuals or couples are called upon to make. Becoming a responsible parent involves a sustained commitment to economic, social and psychological support of the child for at least fifteen and often for more than twenty years. Individuals and couples must assess their current and likely future circumstances over a series of domains, including partnership, employment and income, housing and time commitments (Hobcraft \& Kiernan 1995).

A value is an enduring belief that a specific mode of conductor or end-state of existence is personally or socially preferable to an opposite mode of conduct or end-state of existence. Values are understood as enduring dispositions which guide choices and decisions of individuals (Helkama 2001). The individual's relationship to the surrounding reality is reflected in his or her values. Values are expressed through attitudes, which provide models of behavior, and which develop through life experience (Puohiniemi 1996). There are often logical relations between values and attitudes. For example, values that are identified as being within the specialized concern of a particular institution should be the best predictors of the attitudes and behaviors that are also within that domain: thus religious values should be most associated with religious attitudes and behaviors. (Rokeach 1973.)

In this paper we focus on value orientations and attitudes which we presume to have some influence on fertility decision-making. We examine whether men and women who intend to have less or more than the normative two children hold different values and attitudes in life from others. Are situational factors, such as one's economic situation, more important in determining fertility intentions than values and attitudes? Or are we living in a society with such a diversity of values that conclusions such as this 
are difficult to make, because, for example, work, family, children and time for oneself are all highly valued by most people?

We focus on six value and attitude groups: 1) attitudes towards children, 2) attitudes towards family, 3) attitudes towards work, 4) attitudes towards gender roles, 5) religious values and 6) individualistic values.

Religious values. Religion is a symbol of the past, the legacy of traditional society (Goldscheider 1999). Church attendance has considerably decreased in most countries; however, the timing and pace of this process differs from one country to the next and from one faith to another. The overarching and transcendent religious system has been reduced to a subsystem of society alongside other subsystems, the overarching claims of which have a shrinking relevance. (Dobbelaere 1995.) Traditional religious values are replaced by secular orientations that emphasize the centrality of the individual in decision-making processes and the deliberate or conscious choice they make about the number of children that are appropriate for their economic circumstances (Goldscheider 1999). While society is in general becoming more secular, religious values are still found to have a relation to fertility behavior in many fertility studies.

Individualistic values. Having a child bonds individuals and couples both emotionally and legally for the rest of their lives. Having children requires giving up past liberties, for example free time and work. In an individualized style of living, the birth of a child may stand in the way of people's individual freedom. An individualized lifestyle may therefore go hand in hand with postponing the birth of a child or perhaps with not having children at all. (Jansen \& Kalmijn 2002.) Moors (2002) found strong support for the idea that autonomy values develop in the process of family formation. Autonomy values are specifically relevant in partially explaining the transition to motherhood and the preference for living independently as a woman.

Attitudes towards gender roles. In modern society men and women are expected to show more liberal attitudes towards gender roles. Traditional gender role attitudes prescribe motherhood as an essential characteristic of being a woman, and thus can be expected to bear association to fertility intentions. Thomson (2002) found out in her study that transition to first- or second-time motherhood was not associated with gender role traditionalism but second-time fatherhood was. Berrington (2002) found in her study that women's entry into parenthood was associated with the adoption of more traditional attitudes towards women's work. However the effect differed according to the subsequent labor market experiences of woman. Leaving the labor market to undertake family care was associated with greater approval of traditional family attitudes, while re-entry into the labor market was related to increased egalitarianism. 
Attitudes towards children. In former societies parenthood was beyond dispute, but today a matter of free choice, the outcome of comparing pros and cons, which are personally defined. Nevertheless, children remain important to large parts of the population. The proportion of women and men who do not want any children is small in all European countries, even though there is no longer social pressure to have children (van den Akker, Halman \& de Moor 1993). Schoen et al. (1997) found strong support in their study for their hypothesis that persons for whom relationships created by children are important are more likely to intend to have a(nother) child.

Attitudes towards work. Work in modern society is not only an economic necessity, but also an intrinsically rewarding and creative human activity. Work was one of the most important things in life after family in Western countries in 1990. Work in the information society is very different from traditional work roles in the industrial period. Work is now more flexible, more abstract and more demanding mentally. As a consequence, new work qualifications are required from workers, the emphasis being on commitment, motivation and teamwork. (Zanders 1993.) Comparison of the importance of work values in Europe and North America demonstrated that North Americans obviously demand more from a job than Europeans, but for both continents good pay is of highest importance (Zanders \& Harding 1995).

Attitudes towards family/familistic values. According to the familistic view, the family is a value in itself and includes all thoughts, demands and activities which are directed to making the family stronger (Jallinoja 1984). The birth of the first child is likely to be most strongly related to family values (Thomson 2002). Moors (2002) pointed out in his study that traditional family values increased the likelihood of choosing traditional patterns of family formation like marriage and motherhood. From the traditional point of view, having children is seen even as the ultimate expression of a bond and the fulfilment of a relationship (Jansen \& Kalmijn 2002). More than 80 percent of people in Western countries find the family very important in their lives. It is more important than friends, acquaintances, leisure time, work, religion or politics (van den Akker, Halman \& de Moor 1993).

\section{Study hypotheses}

In this paper we examine whether information on personal value orientations and attitudes add to our knowledge of the determinants of fertility intentions and decisionmaking. We will focus on religious values, attitudes towards children, family and work, attitudes towards gender roles and individualistic values, and assess their impact in addition to demographic and situational factors.

We expect that individualistic values and the drive for self-realization as well as nontraditional sex role attitudes and the importance and meaning given to work reduce childbearing intentions in Finland. We presume that persons who are more individual- 
istic or work-oriented are more actively seeking alternatives for childbearing, while persons who hold more familistic attitudes (centrality of children, preference for traditional family modes) or religious values get more satisfaction from children and the parental role and, thus, are more likely to intend to have (more) children. In addition, it can be expected that persons who value satisfaction and success in working life highly are more likely to perceive the costs related to childbearing and children as being higher, and consequently, more likely to show intentions to stop childbearing at lower parities. We assume, in accordance with other studies indicating a negative relationship between higher order parities and economic constraints, that financial concerns related to children are more relevant in decisions concerning third or higher parity births than in lower parities. In general, we expect that values and attitudes will increase our understanding of fertility intentions and behavior especially in explaining non-normative behavior, e.g. the intention to stay childless and the intention to have a third or higher order child.

\section{Data and methods}

Data from the Finnish Population Policy Acceptance Survey was used for this study. This Finnish survey is a part of the Population Policy Acceptance Survey (PPA2), a comparative cross-sectional survey of Europeans' (12 countries) attitudes and opinions concerning demographic changes, demographic behavior and population-related policies. The survey focused on values and attitudes towards the family and family formation, on the perceptions of the advantages of having children, meanings given to the family and parenthood, aspirations in life, as well as opinions and attitudes towards population policy issues and family policy measures and the role of government in providing social security. The survey also included questions on fertility intentions.

The Finnish survey was conducted in spring 2002. A simple random sample of 7,000 men and women aged 18-69 years and living in Finland (excluding the Province of Alland) was drawn from the population register by the Population Register Center. A questionnaire was mailed twice, with one mailing of a letter including only a return request to all persons in the sample. The overall response rate achieved was 55.7 percent, which is relatively low compared to response rates received from interview studies. For this study the sample was restricted to 18-40-year-old women and men with $0-2$ children. Pregnant women or men whose partner was pregnant were excluded from the study. The size of the sub-sample for this study is 1,237 persons. In the Finnish data, men below 40 years of age and women aged 18-19 and 30-34 years were somewhat underrepresented. There was also a slight underrepresentation of married and divorced men aged 30-34 and single women aged 18-19 and 30-34. Persons with a university degree were clearly overrepresented in the data. Men and women without children and men with two children were slightly underrepresented and men and women with one child overrepresented in the data set. 
Our focus of interest for this study is in questions concerning values in life, such as religiousness and individualism, and attitudes towards children, family, work and gender roles and the impact these have on birth intentions.

The PPA2 questionnaire included a number of questions related to values and attitudes. In a preliminary analysis, we conducted factor analyses to construct as reliable indicators of values and attitudes as possible. If it was not possible to create a factor, a single indicator was used instead.

Logistic regression is the main analytical tool used in this study. At first we describe men's and women's fertility intentions according to parity, and second, analyze determinants of intentions. We examine parities 0,1 and 2 separately to test the hypothesis of parity-specific associations.

First, we examine factors associated with a decision to stop childbearing versus a more or less certain intention to continue childbearing (in logistic regression terms ' 0 ' included those who had given a 'no' response to the question on childbearing intention and ' 1 ' those who had either responded 'uncertain' or 'yes'). In the next phase, we focus on those who had indicated at least some potential to continue childbearing by opposing 'uncertain' to 'yes' responses to investigate factors related to certainty of the intention.

Logistic regression analyses are performed separately for each parity group. For each parity group, the models include control variables (age, gender, type of union and age of the youngest child for parities 1 and 2), and other background variables describing situational factors (educational level, employment and income). The association of the value orientation and attitude variables to the dependent variable will be examined each in turn in models which include control and situational variables. Our focus will be in examining the net association of values and attitudes and childbearing intentions when the impact of demographic and other background variables has been controlled for ${ }^{1}$. In our examination we have also included variables which did not prove to have a significant impact, or even exceeded the criteria (p-value $<0.25$ ) suggested by Hosmer \& Lemeshow (2000) in the preliminary analyses (in which we examined models including only age/age of the youngest child as a control variable

\footnotetext{
${ }^{1}$ Alternative models were tested to examine whether the results presented here would hold up. Especially since the number of cases in each parity group was relatively small, we examined the impact of factors on intentions in models for all parities $1+$, and in models for parities $2+$, and included parity* factor-interaction terms. None of these models provided additional information to the models presented here. Also, collapsing union categories did not change the results markedly. When focusing only on persons in a union, we found that attitudes towards gender roles (the more traditional the attitude towards women's role was) significantly increased the certainty of intention, and the intention to stop or continue was significantly associated with a positive attitude towards children (the more negative the attitude was, the more likely the person was to say 'no' to (further) childbearing intentions).
} 
and each value/attitude variable in turn), in order to examine factors that have proven significant in other studies.

Only the coefficients of value/attitude variables included in the paper are presented in Table 3. The impact of control and situational variables are discussed only shortly (models which present the impact of control and situational variables (only) are presented in Appendix table 3). The figures in Table 3 are odds ratios and obtained from the estimated logit coefficients (b) by transformation $\mathrm{e}^{\mathrm{b}}$. While the interpretation of the impact of a continuous variable is generally in the form 'b gives the change in the $\log$ odds for an increase of one unit in the independent variable', e.g. the likelihood to exhibit the examined outcome increases/decreases by $\mathrm{e}^{\mathrm{b}}$ by every unit in the independent variable, a one-unit change in an attitude/value variable is more difficult to understand. As the magnitude of the change is dependent on the measurement scale of the independent variable, we will therefore focus on the significance and direction of the association.

\section{Dependent variable}

The dependent variable used in this analysis was the intention to have a child. Fertility intentions were measured by the question: "Do you intend to have a(nother) child in the future?" Response options were: 1) No, 2) Don't know, uncertain and 3) Yes. The fourth category, '4 I am/my partner is pregnant' was excluded from the study.

We understand uncertainty as a state between yes and no, in the sense that there is at least a potential 'mental state' for yes, but the person's life situation is not right just now, for example because of an insecure job or economic situation. Since the PPA2questionnaire did not include any additional questions concerning the certainty of 'yes' and 'no' options, nor were there any indicators on timing expectations, we treat the dependent variable as a two-category variable. First we examine the association of covariates to the propensity to say no versus uncertain/yes, and in the second phase, uncertain versus yes to the question about birth plans. This means that we first examine factors related to intention to stop or continue childbearing, and next, factors related to the certainty of the intention to continue.

\section{Determinants of fertility intentions}

Independent factors can be divided into three groups: 1) control variables (sex, age, marital status, interval between births), 2) situational factors reflecting the individual's social and economic circumstances (education, at work or not at work, and income) and 3) value and attitude factors. 


\section{Control variables}

We included some characteristics of the respondents in the models as control variables in order to eliminate some potential direct effects on childbearing intentions. A cross-sectional study on fertility intentions among women and men of different ages and number of children reflects the respondents' current stage of reproductive and family life, as Ruokolainen and Notkola (2002) have also pointed out. Consequently, some of those who had intended to have a(nother) child in the beginning of their fertile age, or soon after marriage/previous child, had already done so, and proceeded to higher parities by the time of the survey. Those who remain in the lower parity group have either not yet realized their intention to have another child, or intend not to have (subsequent) children. Accordingly, the age of the respondent (used in the models as a three- or two-category variable, 18-25, 26-33, 34-40, or 18-33, 34-40 in parities 1 and 2) and, in models for parities 1 and 2, age of the youngest child (0-5 years and $6+$ years) attempt to eliminate bias caused by the respondents being in different stages of life.

PPA2 data provided the opportunity to examine also men's childbearing intentions. Studies of couples' decision-making have pointed to the importance of also including men's fertility desires (cf. Thomson et al. 1990), although unfortunately we could not benefit from couple data in this study. We expected that gender would also influence the impact of values and attitudes to childbearing intentions, and performed an additional analysis with models which included interaction terms for gender and value/ attitude variables.

Marital status has been found to have an impact upon childbearing intention (for example Thomson 1997; Schoen et. al 1999), and we included it as a three-category variable (married-in a consensual union-not living in a union). Persons living in a consensual union and those who did not live in a union were kept in separate categories since the proportion of births to cohabiting couples increased rapidly in Finland at the turn of the 1990 's. A preliminary analysis showed also that the impact of these two groups on childbearing intentions was different depending on whether we were analyzing 'no' versus 'uncertain/yes' or 'uncertain' versus 'yes' responses. In addition to time variables, marital status reflects the family formation stage. In most cases, persons living in a consensual union or those not in a union are generally in the beginning phase of their family life, while married persons have lived in their union longer, and are more likely to have had a(nother) child. We conducted an additional analysis for respondents living in a marriage or consensual union only, but the results did not differ markedly from those presented in this paper.

\section{Situational variables}

Studies have suggested that economic and employment-related considerations (situational factors) can be more important factors when a couple is planning for a third or subsequent child than in lower parity births (Namboodiri 1974; Schoen et al. 1997; 
Ruokolainen \& Notkola 2002). Education is generally believed to influence childbearing, although its impact may be more visible in the timing of births, those with a higher educational background starting later and ending up with a lower number of children.

In this study we used educational attainment, work attainment and income as a measure of the respondent's socioeconomic situation. Because of the relatively small number of respondents in the relevant age groups, we created rather crude categories for situational factors. We divided educational level into two groups: university degree and lower than university degree education. Work attainment was divided also into two groups: at work and not at work, which also included persons working less than 10 hours a week (only 1.2 percent of the respondents were working less than 10 hours per week). Especially among women, higher educational level and employment are generally expected to have a negative relationship to childbearing. Economic situation was measured by monthly income of the total household, which was divided in three groups of equal size: lowest, middle and highest salary group.

Appendix table 1 presents the distribution of the respondents by control and situational variables.

\section{Values and attitudes}

We will evaluate the impact of several different values/attitudes on childbearing intentions: religious values, individualistic values, attitudes towards children (economic considerations and personal pleasure), family values (children as a social resource and attitudes towards family forms), attitudes towards work (money, success and satisfaction) and gender roles (equality and role model). The composition of value and attitude variables is described in Table 1 (see next page), and information on the related factor analyses is presented in Appendix table 2.

Table 2 presents mean scores for values and attitudes used in the study by sex. There were some differences in opinions between men and women (in Table 2 on page 215), the statistical significance of the difference is indicated). Men valued religion a little less than women and thought more often that children mean an economic burden to their parents. Women had a little more modern attitude towards family forms, but men more often thought of children as a social resource. For women it was more important to be satisfied at work than it was for men, and women were more modern in their gender role attitudes and valued equality in the family more than men did. 
Table 1. Composition of value and attitude variables.

\begin{tabular}{ll}
\hline Value/attitude & Indicator(s) \\
\hline Religious values & $(1)$ A single item "What role does religion play in your life?"
\end{tabular}

Religious values

(1) A single item "What role does religion play in your life?"

Response options ranged from $1=$ a very important role to $4=$ no role at all.

Individualistic values

(1) A factor 'Individualistic values' was created from three items:

(a) "Having enough time for yourself and for your own interests",

(b) "Having enough time for your friends" and (c) "Self-realization".

Measurement scale from $1=$ very important to $5=$ very unimportant.

Attitudes towards

children

(1) A single item "Children mean an economic burden to their parents", to indicate the importance of economic considerations related to children. Measurement scale from $1=$ strongly agree to $5=$ strongly disagree.

(2) A factor 'Children as personal pleasure' was created from five items: (a) 'I believe that in our modern world the only place where you can feel completely happy and at ease is at home with your children",

(b) "I always enjoy having children near me", (c) "I believe you can be perfectly satisfied with life once you have been a good mother or father", (d) "I like having children because they really need you" and (e)

"I do not believe that you can be really happy if you do not have children." Measurement scale from $1=$ strongly agree to $5=$ strongly disagree.

Attitudes towards family, (1) A factor 'Children as a social resource' was created from three familistic values items: (a) "I believe it is your duty towards society to have children", (b) "Children make a family" and (c) "Children mean security for old age". Measurement scale from $1=$ strongly agree to $5=$ strongly disagree. (2) A factor 'Attitude towards family forms' was created from five items: (a) "If a woman wants to have a child as a single parent, and she doesn't want to have a stable relationship with a man she should be able to", (b) "People who want children ought to get married", (c) "It is all right for a couple to live together without intending to get married", (d) "Marriage is the only acceptable way of living together for a man and a woman" and (e) "It is totally acceptable that young people have many relationships before a stable relationship and having a family". Measurement scale was $1=$ agree and $2=$ disagree

Attitudes towards work (1) A single item: "How important it is to you to be satisfied in your job?"

(2) A single item: "How important it is to you to be successful in your work?"

(3) A single item: "How important it is to you to have enough money/income?"

Measurement scale from 1=very important to $5=$ =very unimportant in all three.

Attitudes towards gender (1) A single item: "How important it is to you to have equal division of roles work between the man and woman in the family?" to indicate the importance of equality in the family. Measurement scale from 1=very important to $5=$ very unimportant.

(2) A factor 'Role model attitude' was created from two items: (a) "In their job women are less ambitious than men" and (b) "No one can take care of a child as well as the mother". Measurement scale from $1=$ strongly disagree to $5=$ strongly agree. 
Table 2. Values and attitudes used in the study, by sex $(\mathrm{N}$, mean and standard deviation).

\begin{tabular}{|c|c|c|c|c|}
\hline & $\begin{array}{c}\text { Men } \\
\text { Mean } \\
\text { (Std.Dev) }\end{array}$ & $\begin{array}{l}\text { Women } \\
\text { Mean } \\
\text { (Std.Dev) }\end{array}$ & $\begin{array}{l}\mathrm{N} \\
\text { men/women }\end{array}$ & Sig. \\
\hline $\begin{array}{l}\text { RELIGIOUS VALUES } \\
1=\text { very important role, } 4=\text { not role at all }\end{array}$ & $\begin{array}{l}2.87 \\
(0.80)\end{array}$ & $\begin{array}{c}2.64 \\
(0.77)\end{array}$ & $509 / 719$ & $* * *$ \\
\hline $\begin{array}{l}\text { INDIVIDUALISTIC VALUES } \\
1=\text { very important, } 5=\text { very unimportant }\end{array}$ & $\begin{array}{c}2.10 \\
(0.57)\end{array}$ & $\begin{array}{l}2.06 \\
(0.58)\end{array}$ & $509 / 719$ & - \\
\hline $\begin{array}{l}\text { ATTITUDES TOWARDS CHILDREN } \\
\text { Children mean an economic burden to their } \\
\text { parents } \\
1=\text { strongly agree, } 5=\text { strongly disagree }\end{array}$ & $\begin{array}{c}3.14 \\
(1.07)\end{array}$ & $\begin{array}{c}3.43 \\
(1.07)\end{array}$ & $449 / 707$ & $* * *$ \\
\hline $\begin{array}{l}\text { Children as a source of personal pleasure to their } \\
\text { parents } \\
1=\text { strongly agree, } 5=\text { strongly disagree }\end{array}$ & $\begin{array}{c}3.09 \\
(0.73)\end{array}$ & $\begin{array}{c}3.04 \\
(0.77)\end{array}$ & $497 / 702$ & - \\
\hline \multicolumn{5}{|c|}{ ATTITUDES TOWARDS FAMILY (FAMILISTIC VALUES) } \\
\hline $\begin{array}{l}\text { Children as a social resource } \\
1=\text { strongly agree, } 5=\text { strongly disagree }\end{array}$ & $\begin{array}{c}3.14 \\
(0.80)\end{array}$ & $\begin{array}{c}3.35 \\
(0.77)\end{array}$ & $499 / 703$ & $* * *$ \\
\hline $\begin{array}{l}\text { Attitude towards family forms } \\
1=\text { modern and } 2=\text { conservative }\end{array}$ & $\begin{array}{c}1.22 \\
(0.28)\end{array}$ & $\begin{array}{c}1.15 \\
(0.25)\end{array}$ & $509 / 718$ & $* * *$ \\
\hline $\begin{array}{l}\text { ATTITUDES TOWARDS WORK } \\
\text { How important it is to you to be satisfied in your } \\
\text { job? } \\
1=\text { very important, } 5=\text { very unimportant }\end{array}$ & $\begin{array}{l}1.73 \\
(0.66)\end{array}$ & $\begin{array}{l}1.66 \\
(0.59)\end{array}$ & $515 / 721$ & + \\
\hline $\begin{array}{l}\text { How important it is to you to be successful in } \\
\text { your work? } \\
1=\text { very important, } 5=\text { very unimportant }\end{array}$ & $\begin{array}{c}2.28 \\
(0.81)\end{array}$ & $\begin{array}{c}2.35 \\
(0.81)\end{array}$ & $513 / 721$ & - \\
\hline $\begin{array}{l}\text { How important it is to you to have enough } \\
\text { money/income?" } \\
1=\text { very important, } 5=\text { very unimportant }\end{array}$ & $\begin{array}{c}1.98 \\
(0.74)\end{array}$ & $\begin{array}{c}2.02 \\
(0.72)\end{array}$ & $515 / 721$ & - \\
\hline $\begin{array}{l}\text { ATTITUDES TOWARDS GENDER ROLES } \\
\text { How important it is to you to have an equal } \\
\text { division of work between the man and woman in } \\
\text { the family? } \\
1=\text { very important, } 5=\text { very unimportant }\end{array}$ & $\begin{array}{c}2.30 \\
(0.92)\end{array}$ & $\begin{array}{l}1.97 \\
(0.84)\end{array}$ & $511 / 721$ & **** \\
\hline $\begin{array}{l}\text { Role model attitude } \\
1=\text { modern, } 5=\text { traditional }\end{array}$ & $\begin{array}{c}2.79 \\
(0.82)\end{array}$ & $\begin{array}{c}2.65 \\
(0.82)\end{array}$ & $514 / 719$ & ** \\
\hline
\end{tabular}

$+\mathrm{p}<=0.1, * \mathrm{p}<=0.05, * * \mathrm{p}<=0.01, * * * \mathrm{p}<=0.001$, difference between men's and women's mean scores 


\section{Results}

\section{Fertility intentions among men and women}

Figures 1 and 2 present the distribution of fertility intentions among men and women according to parity.

Only eight percent of men and nine percent of women without children said they did not intend to have children at all, about every third was uncertain and half intended to have children. One child is also not very often the desired number of children in a family, because only 16 percent of mothers of one child and 19 percent of fathers did not intend to have more children. Although childlessness or only one child in a family are not wished for by many, still about 15 percent of Finnish women are childless and 20 percent have only one child at the age of 50 years (Statistics Finland 2001).

Figure 1. Men's fertility intentions in different parities $(\mathrm{N}=515), \%$.

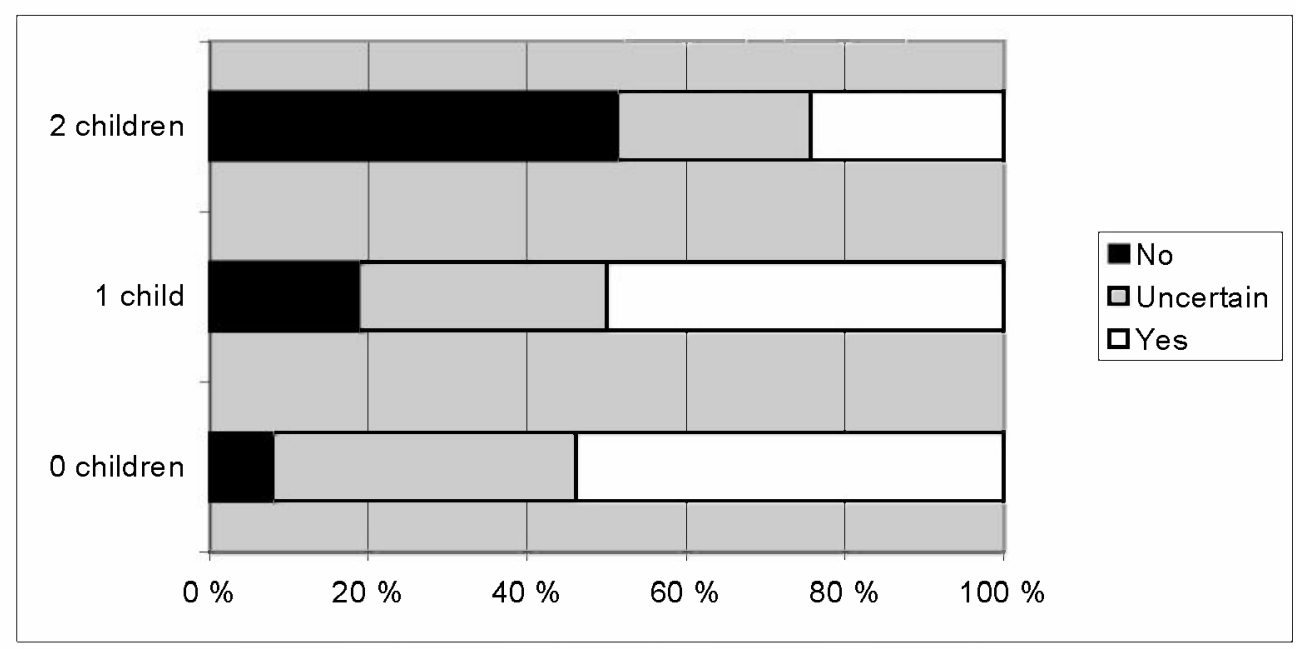

(Parity $0: \mathrm{N}=353$, parity $1: \mathrm{N}=80$, parity $2: \mathrm{N}=82$ )

About two children has been the average family size in Europe for the last sixty years (Coleman 1996). The norm of two children in a family was visible also in this study. After having two children especially the intentions of women to have more children drop, and uncertainty and intention not to have more children grow. Among parents with two children there are more men than women who intend to have more children and more women than men who are uncertain about having more children. 
Figure 2. Women's fertility intentions in different parities $(\mathrm{N}=722), \%$.

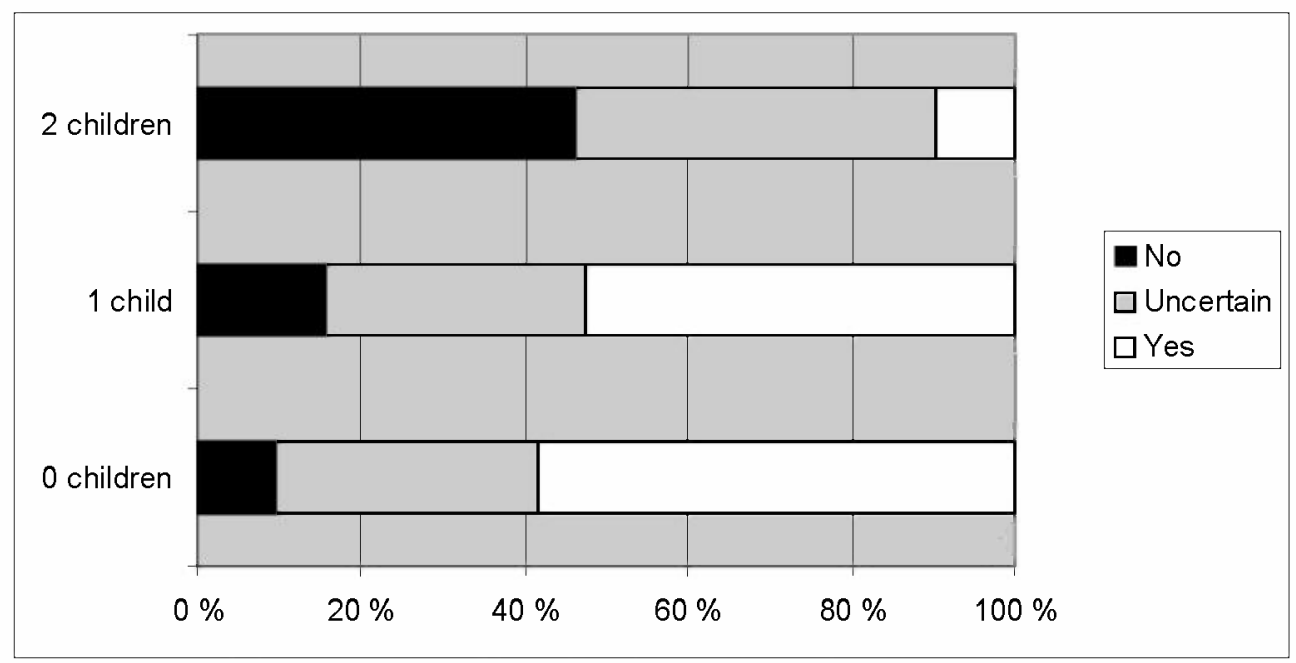

(Parity $0: \mathrm{N}=422$, parity $1: \mathrm{N}=135$, parity $2: \mathrm{N}=165$ )

\section{Factors related to childbearing intentions}

\section{Control and situational factors}

The age of the respondent and the age of the youngest child were negatively associated with an intention to have (more) children. (Models which include both the control and the background variables but not value/attitude variables are presented in Appendix table 3.) Since these variables reflect the stage of life of the respondents, results are as expected. Gender affected intentions only in two cases: women were more likely to say no to childbearing at parity zero than men were and, also, less certain to proceed towards a third birth.

There was no marked difference between marriage and a consensual union in childbearing intentions. On the other hand, the lack of a suitable partner was associated with intentions but the pattern was mixed. In parities zero and one, the lack of a suitable partner decreased the certainty of the intention to bear a child, but it was not significantly associated with the intention to stop/continue childbearing. At parity two, not living in a union increased the likelihood to plan for a third child.

Education was positively associated with plans to continue childbearing, and with certainty of the intention to have (more) children (the association was statistically significant only at parity zero). Persons with a university degree were more likely to plan for (more) children. This again may reflect the stage of life of the respondents, since education is related to postponement of childbearing, and persons with a higher 
educational degree have started to proceed towards the desired number of children later than the others.

Neither employment status nor income had a marked impact upon intentions. Employment was significantly related to childbearing intentions only at parity zero. Being employed increased the likelihood to plan childbearing. Only certainty of intention at parity one was significantly, and, surprisingly, negatively associated with income. It may be that state policies are able to reduce costs related to childbearing to the extent that neither employment status nor income has a significant role concerning childbearing intentions. It is also possible that employment-related factors are more important in determining the timing of the births.

\section{Values and attitudes}

Contrary to our expectations, religion was not generally associated with the intention to have children (Table 3). Only at parity zero was the respondent more likely to plan on having children, the more important religion was in her/his life. We were particularly surprised to find that at least with this data, intention and certainty to proceed towards a third birth failed to be significantly associated with religiousness. While the impact of religiousness was not apparent in the overall intention to have more children, it may have an impact on the timing of parenthood by encouraging earlier and faster childbearing

Values and attitudes related to children had a significant association with intentions in four of our models. Personal pleasure and affection related to children was associated with childbearing intentions and the certainty of the intentions at parities zero and two. The more respondents valued children as sources of personal affection and pleasure, the more likely they were to plan to have (more) children, and the more certain they were in their intentions. Financial considerations associated with children were present in decision-making at zero parity. Persons who feared economic costs related to children were less likely to plan for the first child, or less certain in their intentions. Again, it was somewhat surprising that there was no significant association of financial considerations and childbearing intentions at higher parities.

The "Children as a social resource" -variable was also associated with childbearing intentions. The importance of children as a social resource had a significant and positive relationship at parity zero to the intention to start childbearing and to the certainty of the intention. At higher parities, the social resource variable was not significant. It is possible that already one child is enough to fulfil the meaning of children as constitutive of a family while the importance of children in providing old-age security is diminished in modern society. On the other hand, another variable measuring traditional attitudes towards family and family forms was significant at parity two. Those who held more conservative attitudes towards family forms were more likely to plan for a third child, and more certain in their intentions. 
Table 3. Odds ratios of intending to stop childbearing versus intending to continue (no vs. uncertain/yes), and of the certainty of the intention to continue (uncertain vs. yes) by parity.

\begin{tabular}{|c|c|c|c|c|c|c|}
\hline \multirow[b]{2}{*}{ Variable } & \multicolumn{2}{|c|}{$\begin{array}{l}\text { Parity 0 } \\
\end{array}$} & \multicolumn{2}{|c|}{ Parity 1} & \multicolumn{2}{|c|}{ Parity 2} \\
\hline & $\begin{array}{l}\text { No vs. } \\
\text { Uncertain/ } \\
\text { Yes }\end{array}$ & $\begin{array}{l}\text { Uncertain } \\
\text { vs. Yes }\end{array}$ & $\begin{array}{l}\text { No vs. } \\
\text { Uncertain/ } \\
\text { Yes }\end{array}$ & $\begin{array}{l}\text { Uncertain } \\
\text { vs. Yes }\end{array}$ & $\begin{array}{l}\text { No vs. } \\
\text { Uncertain/ } \\
\text { Yes }\end{array}$ & $\begin{array}{l}\text { Uncertain } \\
\text { vs. Yes }\end{array}$ \\
\hline $\begin{array}{l}\text { Religion } \\
\text { (1=very important } \\
\text { role) }\end{array}$ & $0.52 * *$ & 0.91 & 0.65 & 0.93 & 1.12 & 0.75 \\
\hline \multicolumn{7}{|c|}{ Values related to children } \\
\hline $\begin{array}{l}\text { Economic burden } \\
\text { (1=strongly agree) }\end{array}$ & $1.49^{*}$ & $1.19 *$ & 1.18 & 1.24 & 0.93 & 1.13 \\
\hline $\begin{array}{l}\text { Personal pleasure } \\
(1=\text { strongly agree })\end{array}$ & $0.19 * * *$ & $0.33^{* * *}$ & 0.87 & 0.68 & $0.66+$ & $0.37 * *$ \\
\hline $\begin{array}{l}\text { Familistic values } \\
\text { Children as a social } \\
\text { resource } \\
\text { (1=strongly agree) }\end{array}$ & $0.27 * * * *$ & $0.54 * * *$ & 0.99 & 0.95 & 0.81 & 0.81 \\
\hline $\begin{array}{l}\text { Attitudes towards } \\
\text { family forms } \\
\text { (1=modern) }\end{array}$ & 1.22 & 0.78 & 1.08 & 0.44 & $3.10+$ & $5.29 *$ \\
\hline $\begin{array}{l}\text { Work } \\
\text { Satisfaction in job } \\
\text { (1=very important) }\end{array}$ & 0.77 & 1.00 & 2.04 & 0.74 & 1.39 & 0.78 \\
\hline $\begin{array}{l}\text { Successful in work } \\
\text { (l=very important) }\end{array}$ & 0.99 & 0.90 & 1.19 & 1.44 & 0.92 & 0.99 \\
\hline $\begin{array}{l}\text { Enough money } \\
\text { (1=very important) }\end{array}$ & 1.05 & 1.13 & $2.60+$ & 1.25 & 1.21 & 1.22 \\
\hline $\begin{array}{l}\text { Individualistic values } \\
\text { (1=very important) }\end{array}$ & $1.69+$ & 1.01 & 1.14 & 1.49 & 1.10 & 1.53 \\
\hline $\begin{array}{l}\text { Gender roles } \\
\text { Equal division of } \\
\text { work in the family } \\
\text { (l=very important) }\end{array}$ & 0.78 & $0.73^{* * *}$ & 1.14 & $0.60^{*}$ & 1.12 & $0.54+$ \\
\hline $\begin{array}{l}\text { Role model } \\
\text { (1=modern) }\end{array}$ & 0.87 & 0.83 & 1.74 & 0.68 & 1.11 & 0.62 \\
\hline
\end{tabular}

Attitudes towards work were generally not related to fertility intentions. We explored a number of factors related to work in addition to single indicators, but could not find any significant relationships. Only at parity one did we find a weak association of the money variable with intentions. The less important it was to the respondent to have enough money, the more likely he/she intended to have a second child. However, a number of work-related factors were differently related to intentions among men and women at lower parities. At parity zero, the importance of being satisfied in one's job was significantly and negatively related to women's and positively to men's intention to start childbearing. The more important it was to have enough money, the less likely women were to plan childbearing (significant at $p<0.05$ level), while among men there was a positive association with the importance of money and childbearing intentions. The certainty of intention at parity zero was, on the other hand, negatively associated with the importance of money among men and positively among women. At parity one, the importance of being successful in work was positively associated 
with the intention to proceed towards a second birth among women and negatively among men.

While work-related attitude factors could be understood as indicators of individualistic values, we also examined a separate factor measuring the importance of self-realization in life. This factor had, however, only a weak relationship to intentions. At parity zero, the individualism variable was negatively associated with plans to have a first child.

Finally, we also investigated variables measuring attitudes towards gender roles. We expected that more modern views about gender relations would imply intentions to have fewer children. However, only the equality variable had a significant association with fertility intentions. The importance of equal division of work in the family was positively associated with the certainty of intention at all parities. It may be that couples who value equality highly also have a predisposition to behave accordingly, and costs related to child care which usually fall on the mothers are reduced by more equal sharing of household tasks. One reason for the failure of the role model variable in explaining intentions may be that the factor was created from only two indicators, which did not correlate very strongly. The interaction of sex and the gender role variables was significant only in one case. At parity zero women who held more modern role attitudes were more likely to plan staying childless.

\section{Summary and discussion}

In conclusion, the results from the Finnish PPA2 survey provided support to the hypothesis that also values and attitudes are associated with childbearing intentions and decisions.

Religious values seemed to have only a minor impact in explaining fertility intentions among Finnish men and women. Attitudes related to children and especially the meaning of children as personal pleasure, on the other hand, had a marked effect on childbearing intentions. Financial considerations influenced intentions at parity zero, as did the attitude towards children as a social asset. Familistic values were related also to thirdbirth intentions. Work-related attitudes and individualistic values appeared to have hardly any impact upon fertility intentions in this data. However, the analysis of the models, which included interaction terms, provided some evidence that the effect of work values may be different among men and women. Attitudes towards gender roles had an impact only when attitude towards the equal division of work was examined.

Situational factors, and especially those related to employment and the economic situation of the family, were only marginally related to fertility intentions. Employment 
status was associated with fertility intentions at parity zero, where persons who were unemployed were more likely to intend to stay childless. Since we had only a very crude indicator for employment, it is possible that an indicator which would better account, for example, for employment history, terms of employment or other employment characteristics would be more useful in explaining fertility intentions and behaviors. Income had a significant and negative impact only on the certainty of the intention to continue childbearing at parity one. The impact of education may be more a reflection of the respondent's stage of life and the fact that persons with more education postpone their childbearing to a later age.

The variation of the impact of both situational and value/attitude variables also supports the notion that intentions and decision-making concerning childbearing are parity-specific. The norm of two children in the family may partly explain the fact that value/attitude variables had hardly any role at all in explaining intentions to proceed towards a second birth. It seems that today people are planning the timing of the first birth very carefully, and often want to postpone it until having finished education and having found a job (Paajanen 2002). Thanks to reliable and effective contraceptive methods the timing of births is more possible than ever before. While situational and economic factors did not have as marked a role in determining intentions to have children as we would have expected, it may well be that they are more important in determining the timing of the first or subsequent birth, and not the general intention to have (more) children.

Children and the family are still widely valued in today's society, and only a few wish to have no children or family at all. Having children and a family may be a part of the idea of self-fulfilment in postmodern society but they compete with other preferences and priorities, as already pointed out by van de Kaa (2001). Treating work and family as opposite expressions of some inherent value orientation may not also be very fruitful, since modern men and women appear to value them both very highly in their lives. It is possible that diverse results from studies on fertility and values may be partly caused by indicators for attitudes and values being neither very well developed nor shared. In this study also, more detailed and specified indicators on, for example, sex roles and the importance of different aspects of work in one's life might have provided additional information on how attitudes towards changing sex roles as well as towards work interfere with fertility decisions.

Future investigation of intentions should also include more detailed analysis on timing intentions, as well as provide information on the impact of intentions and actual fertility behavior. In these studies, data on a couple's decision-making and characteristics of the union would also increase our knowledge of fertility determinants (see for example Thomson 1997). 
While the connection between values and attitudes and fertility behavior is not always clear and the direction of the impact is difficult to establish in a cross-sectional study, we think that research on personal values and attitudes in relation to fertility behavior can give new and important views in addition to other fertility determinants. Particularly values and attitudes may have a meaningful role in explaining childbearing decisions at 'marginal' parities zero and three or more. In the future, PPA2 studies conducted in other European countries will provide data to examine whether the same attitudes and values are related to fertility intentions in a similar fashion among other Europeans.

\section{References}

Becker, G. 1993. A Treatise on the family. Enlarged edition. Cambridge, Massachusetts: Harvard University Press.

Bulatao, Rodolfo, A. 1981. Values and disvalues of children in successive childbearing decisions. Demography 18(1):1-25.

Coleman, David. 1996. New patterns and trends in European fertility: International and subnational comparisons. In: Europe's population in the 1990's, edited by David Coleman, pp. 1-61. New York: Oxford University Press.

Dobbelaere, Karel. 1995. Religion in Europe and North America. In: Values in western societies, edited by Ruud de Moor, pp. 1-30. Tilburg: Tilburg University Press.

Easterlin, R. A.. 1966. On the relation of economic factors to recent and projected fertility changes. Demography 3:131-153.

Friedman, Debra, Michael Hechter and Satoshi Kanazawa. 1994. A theory of the value of children. Demography 31:375-401.

Goldscheider, Calvin. 1999. Religious values, dependencies and fertility: Evidence and implications from Israel. In: Dynamics of values in fertility change, edited by Richard Leete, pp. 310-330. New York: Oxford University Press.

Helkama, Klaus. 2001. Arvot, sosiaaliset representaatiot ja asenteet [Values, social representations and attitudes] In: Johdatus sosiaalipsykologiaan [Introduction to social psychology], edited by Klaus Helkama, Rauni Myllyniemi \& Karmela Liebkind, pp. 177210. Helsinki: Edita.

Hobcraft, John and Kathleen Kiernan.1995. Becoming a parent in Europe. In: Evolution or revolution in European population, edited by Chiara De Bernardi and Patrizia Farina, pp. 27-65. Milano: FrancoAngeli.

Hoffman, Lois Wladis and Jean Denby Manis. 1979. The value of children in the United States: A new approach to the study of fertility. Journal of Marriage and the Family 41(3):583-596.

Hosmer, David \& Lemeshow, Stanley. 2000. Applied Logistic Regression. 2nd edition. New York: John Wiley \& Sons Inc.

Jallinoja, Riitta. 1984. Perhekäsityksistä perhettä koskeviin ratkaisuihin [From images of the family to decisions concerning the family]. In: Perhe, työ ja tunteet. Ristiriitoja ja ratkaisuja [Family, work and feelings. Conflicts and solutions], edited by Elina Haavio-Mannila, Riitta Jallinoja and Harriet Strandell, pp. 37-110. Helsinki: WSOY.

Jansen, Miranda and Matthijs Kalmijn. 2002. Investment in family life: The impact of value orientations on patterns of consumption, production and reproduction in married and cohabiting couples. In: Meaning and choice: Value orientations and life course decisions, edited by Ron Lesthaeghe, pp. 129-159. The Hague: NIDI CBGS Publications. 
Lesthaeghe, Ron. 1983. A century of demographic and cultural change in western Europe: An exploration of underlying dimensions. Population and Development Review 9(3):411-435.

Miller, Warren, B. and David J. Pasta. 1995. Behavioral intentions: Which ones predict fertility behavior in married couples? Journal of Applied Social Psychology 25(6):530-555.

Moors, Guy. 2002. Reciprocal relations between gender role values and family formation. In: Meaning and choice: Value orientations and life course decisions, edited by Ron Lesthaeghe, pp. 217-250. The Haque: NIDI CBGS Publications.

Monnier, Alain. 1989. Fertility intentions and actual behavior. A Longitudinal study: 1974, 1976, 1979. Population. English Selection Vol 44(1):237-254.

Myers, S.M. 1997. Marital uncertainty and childbearing. Social Forces 75:1271-1289.

Namboodiri, N. Krishnan. 1974. Which couples at given parities expect to have additional births? An exercise in discriminant analysis. Demography 11(1):45-56.

Nikander, Timo. 1992. The woman's life course and the family formation. Population 1992:1. Helsinki: Statistics Finland.

Paajanen, Pirjo. 2002. Perhebarometri 2002. Saako haikara tulla käymään? Suomalaisten lastenhankinnan ihanteet ja todellisuus [Family barometer 2002. May the stork visit you? The Finns' family size ideals and reality]. Katsauksia E 14/2002. Helsinki: Väestöntutkimuslaitos, Väestöliitto.

Palomba, Rossella (1998). Value preferences and attitudes on population. In: Population, family and welfare. A comparative survey of European attitudes. Volume 2, edited by Rossella Palomba and Hein Moors, pp. 51-71. Oxford: Clarendon Press.

Palomba, Rossella and Hein Moors. 1995. Attitudes towards marriage, children, population polices in Europe. In: Population, family and welfare. A comparative survey of European attitudes. Volume 1, edited by Hein Moors \& Rossella Palomba, pp. 245-262. Oxford: Clarendon Press.

Palomba, Rossella and Hein Moors. 1998. The image of the family. In: Population, family and welfare. A Comparative survey of European attitudes. Volume 2, edited by Rossella Palomba and Hein Moors, pp. 72-93. Oxford: Clarendon Press.

Preston, S.H. 1986. Changing values and falling birth rates. In: Below-replacement fertility in industrial societies: Causes, consequences, policies, edited by K. Davis, M.S. Bernstam, and R. Ricardo-Campbell, pp. 176-195. Cambridge: Cambridge University Press.

Puohiniemi, Martti. 1996. Suomalaiset arvot yhteiskunnallisessa muutostilanteessa [The values of Finns in societal change]. In: Elämän riskit ja valinnat - Hyvinvointia lama-Suomessa? [Risks and choices in life - Well-being in Finland under recession?], edited by Kirsti Ahlqvist and Anja Ahola, pp. 30-54. Helsinki: Statistics Finland and Edita.

Rindfuss, R.R., S.P. Morgan and G. Swicegood. 1988. First births in America: Changes in the timing of parenthood. Studies in demography. Berkeley: University of California Press.

Ritamies, Marketta, Olavi Riihinen, Heli Penttinen and Aimo Pulkkinen. 1984. Lapsilukuihanne - toive vai tavoite [Ideal number of children - a wish or a goal of life]. Series D 13. Helsinki: The Population Research Institute, The Family Federation of Finland.

Rokeach, Milton. 1973. The Nature of Human Values. The Free Press.

Ruokolainen, Anne and Irma-Leena Notkola. 2002. Familial, situational and attitudinal determinants of third-birth intentions and their uncertainty. In: Yearbook of Population Research in Finland 38 (2002):179-206. Helsinki: The Population Research Institute, The Family Federation of Finland.

Schoen, Robert, Young, J. Kim, Constance A. Nathanson, Jason Fields and Nan Marie Astone. 1997. Why do Americans want children? Population \& Development Review 23(2):333-358.

Schoen, Robert, Nan Marie Astone, Young, J. Kim and Constance A. Nathanson. 1999. Do fertility intentions affect fertility behavior? Journal of Marriage and the Family 61:790799 . 
Statistics Finland. 2002. Population Structure. Population 2002:6. Helsinki: Statistics Finland Statistics Finland. 2001. Population Structure. Population 2001:6. Helsinki: Statistics Finland Thomson, Elizabeth, Elaine McDonald and Larry L. Bumpass 1990. Fertility desires and fertility: hers, his and theirs. Demography 27(4):579-588.

Thomson, Elizabeth. 1997. Couple childbearing desires, intentions, and births. Demography 34(3):343-354.

Thomson, Elizabeth. 2002. Motherhood, fatherhood and family values. In: Meaning and choice: Value orientations and life course decisions, edited by Ron Lesthaeghe, pp. 251-271. The Hague: NIDI CBGS Publications.

Thornton, Arland. 1989. Changing attitudes toward family issues in the United States. Journal of Marriage and the Family 51:873-893.

van den Akker, Piet, Loek Halman and Ruud de Moor.1993. Primary relations in western societies. In: The individualizing society. Value change in Europe and North America, edited by Peter Ester, Loek Halman \& Ruud de Moor, pp. 97-127. Tilburg: Tilburg University Press.

van de Kaa, Dirk, J. 2001. Postmodern fertility preferences: From changing value orientation to new behavior. In: Global fertility transition, edited by Rodolfo A. Bulatao \& John B. Casterline. Population and Development Review, A Supplement Vol. 27:290-331.

Vikat, Andres. 2002. Fertility in Finland in the 1980s and 1990s: Analysis of fertility trend by age and parity. Yearbook of Population Research in Finland 38 (2002):159-178. Helsinki: The Population Research Institute, The Family Federation of Finland.

White, Lynn, K. \& Hyunju Kim. 1987. The family-building process: Childbearing choices by parity. Journal of Marriage and the Family 49:271-279.

Zanders, Harry. 1993. Changing work values. In: The individualizing society. Value change in Europe and North America, edited by Peter Ester, Loek Halman and Ruud de Moor, pp. 129-153. Tilburg: Tilburg University Press.

Zanders, Harry \& Stephen Harding. 1995. Changing work values in Europe and North America. Continents and occupations compared. In: Values in western societies, edited by Ruud de Moor, pp. 195-216. Tilburg: Tilburg University Press. 
Appendix table 1. Distribution of respondents by background variables.

\begin{tabular}{|c|c|c|c|}
\hline & & Men & Women \\
\hline $\mathrm{N}$ & & 515 & 722 \\
\hline Age & $18-25$ & 37.7 & 40.6 \\
\hline & $26-33$ & 35.7 & 30.2 \\
\hline & $34-40$ & 26.6 & 29.2 \\
\hline No of children & 0 & 68.5 & 58.4 \\
\hline & 1 & 15.5 & 18.7 \\
\hline & 2 & 15.9 & 22.9 \\
\hline Type of union & Married & 24.6 & 31.0 \\
\hline & Consensual union & 29.5 & 31.6 \\
\hline & No union & 45.9 & 37.3 \\
\hline \multirow[t]{2}{*}{ Age of the youngest child (only parities $1+$ ) } & $0-5$ years & 65.0 & 58.6 \\
\hline & $6+$ years & 35.0 & 41.4 \\
\hline \multirow[t]{2}{*}{ Educational level } & Other & 83.1 & 79.3 \\
\hline & University degree & 16.9 & 20.7 \\
\hline \multirow[t]{2}{*}{ Employment status } & Employed & 64.5 & 61.3 \\
\hline & Unemployed & 35.5 & 38.7 \\
\hline \multirow[t]{3}{*}{ Income $(€ /$ month/household $)$} & $\begin{array}{c}\text { Lowest third } \\
(0-1333 €)\end{array}$ & 41.8 & 40.8 \\
\hline & $\begin{array}{c}\text { Middle } \\
(1334-2333 €)\end{array}$ & 30.3 & 30.9 \\
\hline & $\begin{array}{l}\text { Highest } \\
(2334-€)\end{array}$ & 27.9 & 28.3 \\
\hline
\end{tabular}

Appendix table 2. Results of factor analyses.

\begin{tabular}{|c|c|c|}
\hline Factor & Mean & Std Dev \\
\hline $\begin{array}{l}\text { 1. Children as personal pleasure } \\
\text { Eigenvalue } 2.50 \text {, explained variance } 50.0 \% \text {, Cronbach's alfa } 74.2 \\
1=\text { strongly agree }-5=\text { strongly disagree }\end{array}$ & 2.99 & 0.75 \\
\hline $\begin{array}{l}\text { 2. Children as social resource } \\
\text { Eigenvalue } 1.55 \text {, explained variance } 51.7 \% \text {, Cronbach's alfa } 52.6 \\
1=\text { strongly agree }-5=\text { strongly disagree }\end{array}$ & 3.09 & 0.82 \\
\hline $\begin{array}{l}\text { 3. Attitudes towards family forms } \\
\text { Eigenvalue } 2.74 \text {, explained variance } 54.8 \% \text {, Cronbach's alfa } 74.1 \\
1=\text { modern }-2=\text { conservative }\end{array}$ & 1.19 & 0.27 \\
\hline $\begin{array}{l}\text { 4. Individualistic values } \\
\text { Eigenvalue } 1.79 \text {, explained variance } 59.7 \% \text {, Cronbach's alfa } 66.2 \\
\text { 1=very important - 5=very unimportant }\end{array}$ & 2.12 & 0.60 \\
\hline $\begin{array}{l}\text { 5. Role model } \\
\text { Eigenvalue } 1.14 \text {, explained } 56.7 \% \text {, Cronbach's alfa } 23.6 \\
1=\text { modern }-5=\text { traditional }\end{array}$ & 2.74 & 0.84 \\
\hline
\end{tabular}


Appendix table 3. Logistic regression models for determinants of fertility intentions for parities 0,1 and 2 .

\begin{tabular}{|c|c|c|c|c|c|c|c|}
\hline & & \multicolumn{2}{|c|}{ Parity 0 } & \multicolumn{2}{|c|}{ Parity 1} & \multicolumn{2}{|c|}{ Parity 2} \\
\hline & & $\begin{array}{l}\text { No vs. } \\
\text { Uncertain/ } \\
\text { Yes }\end{array}$ & $\begin{array}{l}\text { Uncertain } \\
\text { vs. Yes }\end{array}$ & $\begin{array}{l}\text { No vs. } \\
\text { Uncertain/ } \\
\text { Yes }\end{array}$ & $\begin{array}{l}\text { Uncertain } \\
\text { vs. Yes }\end{array}$ & $\begin{array}{l}\text { No vs. } \\
\text { Uncertain/ } \\
\text { Yes }\end{array}$ & $\begin{array}{l}\text { Uncertain } \\
\text { vs. Yes }\end{array}$ \\
\hline \multirow[t]{3}{*}{ Age } & $18-25$ & 1.000 & 1.000 & - & - & - & - \\
\hline & $\begin{array}{l}26-33 \\
(18-33)\end{array}$ & 0.347 & $0.311 * * *$ & 1.000 & 1.000 & 1.000 & 1.000 \\
\hline & $34-40$ & $0.067^{* * * *}$ & $0.157 * * *$ & $0.148^{* * * *}$ & $0.326^{*}$ & $0.267^{* * * *}$ & 0.766 \\
\hline \multirow[t]{2}{*}{ Sex } & Male & 1.000 & 1.000 & 1.000 & 1.000 & 1.000 & 1.000 \\
\hline & Female & $0.556+$ & 0.955 & 0.833 & 1.041 & 1.375 & $0.173 * * *$ \\
\hline \multirow{2}{*}{$\begin{array}{l}\text { Age of the } \\
\text { youngest } \\
\text { child }\end{array}$} & $0-5 \mathrm{yrs}$ & - & - & 1.000 & 1.000 & 1.000 & 1.000 \\
\hline & $6+y r s$ & - & - & $0.150 * * *$ & 0.516 & $0.438 *$ & $2.992+$ \\
\hline \multirow[t]{3}{*}{$\begin{array}{l}\text { Marital } \\
\text { status }\end{array}$} & Married & 1.000 & 1.000 & 1.000 & 1.000 & 1.000 & 1.000 \\
\hline & $\begin{array}{l}\text { In consen- } \\
\text { sual union }\end{array}$ & 1.091 & 1.046 & 0.950 & 0.626 & 0.945 & 0.371 \\
\hline & No union & 0.531 & $0.477^{*}$ & 1.505 & $0.173^{*}$ & $2.916^{*}$ & 0.253 \\
\hline \multirow[t]{2}{*}{ Education } & Other & 1.000 & 1.000 & 1.000 & 1.000 & 1.000 & 1.000 \\
\hline & University & $1.999+$ & $1.660^{*}$ & 1.548 & 2.571 & 1.864 & 0.425 \\
\hline \multirow{2}{*}{ Employment } & Employed & 1.000 & 1.000 & 1.000 & 1.000 & 1.000 & 1.000 \\
\hline & $\begin{array}{l}\text { Unem- } \\
\text { ployed }\end{array}$ & $0.415^{*}$ & 0.725 & 2.193 & 1.238 & 0.848 & 0.728 \\
\hline \multirow[t]{3}{*}{ Income } & Lowest & 1.000 & 1.000 & 1.000 & 1.000 & 1.000 & 1.000 \\
\hline & Middle & 1.048 & 1.228 & 1.294 & 0.388 & 1.263 & 0.365 \\
\hline & Highest & 1.219 & 1.175 & 0.764 & $0.110^{* *}$ & 0.911 & 0.514 \\
\hline \multirow[t]{3}{*}{ Model } & $-2 L L$ & 321.40 & 713.32 & 106.44 & 179.62 & 267.52 & 110.22 \\
\hline & $\begin{array}{l}\text { Model chi } \\
\text { square }\end{array}$ & 63.62 & 68.13 & 52.76 & 35.92 & 41.59 & 20.57 \\
\hline & $\begin{array}{l}\text { Sig. } \\
N\end{array}$ & .000 & .000 & .000 & .000 & .000 & .015 \\
\hline
\end{tabular}

In the table, figures are exponentiated logistic regression coefficients

$+\mathrm{p}<=0.1, * \mathrm{p}<=0.05, * * \mathrm{p}<=0.01, * * * \mathrm{p}<=0.001$ 